\title{
Alexandra Walsham
}

Catholic Reformation in Protestant Britain. Farnham/Burlington: Ashgate Press, 2014. Pp. Xv + 490. Hb, £8o.

We should be grateful to Ashgate for publishing this collection of twelve of Alexandra Walsham's articles, updated since their first appearances in print between 2000 and 2010. The re-publication is intended to show the development of the author's thinking since the appearance of her Church Papists: Catholicism, Conformity and Confessional Polemic in Early Modern England (1993).

Anyone interested in the history of Catholicism in England and Wales will find this an invaluable work. Note that I have eschewed the term "recusancy," in favor of the word "Catholicism." Walsham wants to emphasize that the latter term is broader and less simplistic. She sees "church papists" as an integral part of a highly porous Catholic community, who created a space between the Church of England and out-and-out Roman Catholicism, which made the existence of recusancy easier. (In Scotland, occasional conformity was not condemned as it was south of the border. The English advocate for such occasional conformity was Thomas Bell, a convert to Catholicism who eventually became a priest. The opposition of both the Jesuits and the secular clergy led Bell to leave the church, ultimately finding work as a polemicist for the Established Church.)

In considering the Counter-Reformation in England, Walsham points out that England lacked one of the movement's primary tools: namely, the diocesan bishop. She argues that the absence of such authorities allowed the laity the freedom to proclaim the sainthood of their martyrs and to maintain some of the customs elsewhere attacked as superstition by the Counter-Reformation episcopate. Yet new currents of spirituality did reach England, through books smuggled into the country and through the priests living in elite homes (usually criticized for ignoring Catholics commoners, but whose rural missionary work is chronicled by Walsham). Walsham cites the religious observance of some of these households, especially the quasi-monastic life of certain laymen. This was a desideratum of the Counter-Reformation, but one that gained little purchase in Catholic households on the continent. More broadly, Walsham also compares the structure of the English and Continental Counter-Reformation(s). She cites John O'Malley, S.J. (28) to the effect that the Counter-Reformation was no topdown reform, but rather a negotiation between the laity and the bishops.

As to the origins of Elizabethan Catholicism, Walsham respectfully differs with some of the early revisionists (e.g., John Bossy and Christopher Haigh) who argued that without the advent of the seminary priest and the Jesuit missions Catholicism would have disappeared in England. By contrast, she sug- 
gests that in 1559 Catholics constituted a majority in England, a fact at the root of the government's fears of crypto-Catholics, recusants, and priests. What appears in hindsight as a fait accompli was no such thing for those seeking to bolster the position of the Elizabethan church. Walsham also asserts that the tenuousness of this situation surfaced at times of tension, whether foreign or domestic. We might thus compare anti-Catholicism to the United States's "Red Scare" of the 1940 s and 1950 s.

The clergy, as depicted by Walsham, seem ambiguous in their thinking about England. Was it a Catholic country to be reclaimed or was it a heretic country to be converted? The same phenomenon occurred simultaneously in Catholic countries, as when Neapolitan Jesuits imagined rural ministry as missions to convert the "barbarians."

Several of the articles consider the relationship between Catholicism and elements of the marvelous: e.g., miracles, Hollywell, and angels. Claims of Catholicism's privileged access to God and to miraculous healing were crucial to the type "missionary" efforts of continental priests. This advantage was complicated by the difficulty of controlling the laity's impulses towards declaring miracles and partaking in certain types of religious expression-largely rooted in pre-Christian folk practices-considered superstitious by post-Trent Catholicism. While the appeal of angels and miracles could induce a "church papist" into recusancy—or even conversion-they also permitted Anglican propagandists to lampoon Catholic credulity and ignorance. Exorcisms were likewise a mixed blessing: while they enacted the spiritual power of the priesthood, they could also turn farcical, if the supposedly possessed individual later admitted to some sort of subterfuge.

Walsham then turns to a fascinating examination of St. Winifred's Well (Hollywell) one of the few medieval shrines to survive-and retain some measure of devotion - through the Reformation. This longevity arose out of a confluence of factors. Henry Garnett, S.J., Anne Vaux, and Robert Catesby led a pilgrimage to Hollywell in the summer of 1605 , some members of which were to join Catesby in the November 1605 Gunpowder Plot. Catholics were by no means the only pilgrims who came in search of a cure: members of the Church of England also visited the well—and, if they found one, frequently converted to Catholicism.

Walsham rejects the "either/or" models at the heart of many treatments of the period: e.g. the only "Catholics" in England were the recusants, while everyone else (whether they knew it or not) acquiesced to the Elizabethan settlement. Such distinctions originate in the (polarized) worldviews of either Catholic or Protestant divines, and are therefore unhelpful for a nuanced understanding of the past. 
On the question of Catholics' relationship to print, Walsham vehemently disagrees with the traditional narrative that regards the printing press as the exclusive preserve of the Protestants. To borrow from the title of one of the essays, she understands Catholic printed works as "dumb preachers." Once again, however, the lack of episcopal oversight allowed matters to move out of strictly orthodox territory. One of seventeenth-century bestsellers in England was a life of Ignatius of Loyola that, when placed on injured parts of the body, was believed to provide cures. Here we find yet another example of expressions of popular religion, caught between the regularizing ideals of the Council of Trent and the resistance of ordinary believers. Analogous situations in these heady years of the Counter-Reformation could easily be found in any of the Catholic lands of the Continent.

This book, especially the first chapter, is an indication of just how dramatically the past fifty years has changed the field of early modern English Catholic studies has for the better. One is tempted to speculate that as religion is taken less and less seriously in England, the more dispassionately the country's Reformation history can be studied.

John J. LaRocca, S.J.

Xavier University

larocca@xavier.edu

DOI 10.1163/22141332-00202007-14 